\title{
A state-of-art review on basic issues on knowledge management
}

\author{
Mohit Maheshwarkar ${ }^{a^{*}}$ and N. Sohani ${ }^{b}$
}

${ }^{a}$ Research Scholar, Institute of Engineering \& Technology, D.A.V.V, Indore (M.P), India ${ }^{b}$ Associate Professor, Department of Mechanical Engineering, Institute of Engineering \& Technology, D.A.V.V, Indore (M.P), India C H R O N I C L E A B S T R A C T

Article history:

Received March 18, 2014

Accepted 26 November 2014

Available online

November 282014

Knowledge

Knowledge Management

KM process

KM objectives

KM benefits

KM myths

KM errors
For many centuries, knowledge has been acting as the backbone of the progress of mankind but very recently it has been supplemented with the concept of management. Yet, the term knowledge management (KM) is being coined very recently and it has gained very huge popularity. Today, organizations have recognized the importance of knowledge management and are continuously working with it. The research paper is dedicated to different aspects of knowledge management and focuses on different views of the researchers on knowledge, knowledge management, KM processes, objectives, benefits, myths and errors.

\section{Introduction}

In recent years, knowledge management has become a critical subject of discussion in the business literature. Both business and academic communities believe that by leveraging knowledge, an organization can sustain its long-term competitive advantages (Bhatt, 2001). KM implementation is one of the major attractions among the researchers and practitioners. The business organizations are more concerned about building the knowledge assets for their competiveness (Singh \& Kant, 2008). Business and academic circles have been conducted on knowledge management for nearly three decades on the research of theory and practice (Tong, 2009). Large numbers of organizations are taking great interest on the idea of knowledge management and many are launching knowledge management initiatives and programs (Storey \& Barnett, 2000). The area of KM is taking on renewed significance with the emergence and ascendancy of the knowledge worker (Maheshwarkar \& Sohani, 2013). Investing in developing the knowledge and capabilities of a company's workforce is becoming a measure of the value of an organization because this investment is now seen as increasing the knowledge content and capability of an organization. At the same time, such an investment also helps to attract the best knowledge workers in a highly competitive knowledge worker market (Binney, 2001). According to Davenport et al. (1998) such knowledge management projects attempts to do something useful with knowledge to accomplish organizational objectives through the structuring of

*Corresponding author.

E-mail addresses: maheshwarkars@yahoo.co.in (M. Maheshwarkar) 
people, technology and knowledge content. Indian organizations too have not been far behind with some using it as an integrated approach towards developing competencies for sustainable competitive advantage. Knowledge management has become increasingly important as organizations realize that effective use of their vast and varied knowledge assets and resources provides them with the ability to innovate and respond to fast changing customer expectations (Zhao, 2011).

\section{Evolution of knowledge management}

Although the term knowledge management formally entered popular usage in the late 1980s (e.g., conferences in KM began appearing, books on KM were published, and the term began to be seen in business journals), philosophers, teachers, and writers have been making use of many of the same techniques for decades (Wells, 1938). The Entovation timeline (available at http://www.entovation.com/timeline/timeline.html) identifies a variety of disciplines and domains that have blended together to emerge as knowledge management. The details of this timeline are given in Table 1.

\section{Table 1}

A Timeline of Knowledge Management

\begin{tabular}{|c|c|c|c|c|}
\hline S. No & Year & Book Publication & Research Event & Initiatives \\
\hline 1. & 1988 & $\begin{array}{l}\text { Know-How Company by Sveiby; Managing } \\
\text { the Knowledge Asset into the } 21^{\text {st }} \text { Century by } \\
\text { Amidon; Mobilizing Invisible Assets by } \\
\text { Itamik. }\end{array}$ & $\begin{array}{l}\text { Prude conference on Roots of } \\
\text { Knowledge Innovation }\end{array}$ & $\begin{array}{l}\text { Creation of offices of technology transfer; } \\
\text { Integration of people and business planning; } \\
\text { European research initiatives; Focus of } \\
\text { manufacturing; Cross Disciplinary research }\end{array}$ \\
\hline 2. & 1989 & Age of Paradox by Handy & $\begin{array}{l}\text { International conference of } \\
\text { Management and } \\
\text { Technology, England }\end{array}$ & Benchmarking \\
\hline 3. & 1990 & $\begin{array}{l}\text { New Realities by Drucker; Slovan Global } \\
\text { Innovation Strategy by Amidon }\end{array}$ & & \\
\hline 4. & 1991 & $\begin{array}{l}\text { Fifth Discipline by Senge; Fifth Generation } \\
\text { Management by Savage; Origins of } \\
\text { Knowledge Based Firm by Amidon; } \\
\text { Knowledge Revolution by Sakniya }\end{array}$ & $\begin{array}{l}\text { Agile Manufacturing } \\
\text { Conference, Teaxas }\end{array}$ & First CKO Edvinsson \\
\hline 5. & 1992 & $\begin{array}{l}\text { Intelligent Enterprise by Quinn; Knowledge } \\
\text { Creating Company by HRB Nonaka; } \\
\text { Leadership and The New Science by Wheatley }\end{array}$ & $\begin{array}{l}\text { Knowledge Management } \\
\text { Conference, Canada; } \\
\text { Knowledge Productivity } \\
\text { Conference } \\
\text { Steelcase/ED S }\end{array}$ & $\begin{array}{l}\text { Creation of European Union; Realization of } \\
\text { Strategy as Leadership; }\end{array}$ \\
\hline 6. & 1993 & $\begin{array}{l}\text { Age of Network by Lipnack and Stamps; } \\
\text { Control Your Destiny or Someone Else Will by } \\
\text { Tichy and Weich Workforce }(2000)\end{array}$ & & $\begin{array}{l}\text { Information Technology as a Competitive } \\
\text { Weapon; Values of Learning Systems Theory; } \\
\text { New view of innovation; }\end{array}$ \\
\hline 7. & 1994 & $\begin{array}{l}\text { Knowledge Management Foundations by } \\
\text { Wiig; Creating Creativity and Innovation in } \\
\text { Large Bureaucracies by Kuhn; Japanese } \\
\text { Technology Transfer by SRC }\end{array}$ & & $\begin{array}{l}\text { Accelerated Computer Communications } \\
\text { Technology; Council on Competitiveness; } \\
\text { Reinventing Government: Networking; }\end{array}$ \\
\hline 8. & 1995 & $\begin{array}{l}\text { Rise and Fall of Strategic Planning by } \\
\text { Mintzberg; The Web of Inclusion by Helgesen; } \\
\text { Information Technology in Services Society by } \\
\text { NRC; Your Company's Most Valuable Asset: } \\
\text { Intellectual Capital by Stewart }\end{array}$ & $\begin{array}{l}\text { Dozons of Knowledge } \\
\text { Conferences (US) }\end{array}$ & $\begin{array}{l}\text { Foundation of Knowledge Media (e.g. FAST } \\
\text { Co., and Knowledge Inc. ); Profiles of } \\
\text { Customer Innovation; }\end{array}$ \\
\hline 9. & 1996 & $\begin{array}{l}\text { Agile Competitors and Virtual Organisations } \\
\text { by Goldman, Nagel and Preise; }\end{array}$ & $\begin{array}{l}\text { Dozens of Knowledge } \\
\text { Conferences (Europe) }\end{array}$ & $\begin{array}{l}\text { Emerging Community of Knowledge Practice; } \\
\text { Explosion of Worldwide Web; The Balanced } \\
\text { Scorecard Technique by Kaplan and Norton }\end{array}$ \\
\hline 10. & 1997 & $\begin{array}{l}\text { Works reported by Davenport, DeKerckhove, } \\
\text { Allee, Prusack,Brooking, Stetwart, } \\
\text { Sveiby,Edvinsson; BI Report by Skyrme and } \\
\text { Amidon; The Ken Awakening by Amidon }\end{array}$ & & $\begin{array}{l}\text { Emerging KM practice begins in Financial, HR, } \\
\text { IT, Quality, R\& D/Technology Transfer, } \\
\text { Engineering, Manufacturing, Marketing/ } \\
\text { Planning, Sales/Service, Alliances/Joint } \\
\text { Ventures }\end{array}$ \\
\hline 11. & 1998 & & & $\begin{array}{l}\text { Knowledge Kaleidoscope; } \\
\text { Entovation R\&D (Beyond } 5^{\text {th }} \text { generation); } \\
\text { Collaborative Innovation Amidon }\end{array}$ \\
\hline 12. & 1999 & & & $\begin{array}{l}\text { Incentives; Certification of Knowledge } \\
\text { Innovation Standards; Awards; Worldwide } \\
\text { Innovation Congress; World's Fair (Germany); } \\
\text { Roundtable for Innovators from Around the } \\
\text { Worked }\end{array}$ \\
\hline 13. & 2000 & \multicolumn{3}{|c|}{ Creation of IMF Equivalent for The World Trade of Ideas } \\
\hline
\end{tabular}




\section{Data, information and knowledge}

According to Bhatt (2001), defining data, information, and knowledge is difficult. Only through external means or from a user's perspectives, one may distinguish between data, information, and knowledge. Tian et al. (2009) say that in many KM literatures it is often pointed out that it was important to distinguish between data, information and knowledge (Tuomi, 1999). Nonaka (1998) made a clear distinction between information and knowledge by defining knowledge as follows. First, knowledge is different from simple information; knowledge is about trust and promise. That is, knowledge functions as a specific attitude, outlook and intention. Second, knowledge is different from information in that it is about certain behaviors. Third, knowledge deals with meanings; knowledge is content-oriented and has a correlation with contents. Knowledge is more than just knowing something. Knowledge is an invisible asset that provides certain standards for decisionmaking and has various individual elements in it, such as personal insights, judgments and improvement skills based on one's learning and experience. Knowledge lies above information in its concept. Facts, data and information go below knowledge. Facts exist objectively and data are the lowest form of certain known facts that essentially have no meaning by themselves (Myburgh, 2000). Zack (1999) argues that data can be considered as facts or observations whereas information is data in a context; knowledge is information that is accumulated and organized in a meaningful way. Tuomi (1999) makes the iconoclastic argument that the often-assumed hierarchy from data to knowledge is actually inverse. He argues that knowledge exists which, when articulated, verbalized, and structured, becomes information which, when assigned a fixed representation and standard interpretation, becomes data. As such, raw data do not exist - even the most elementary piece of data has already been influenced by the thought or knowledge processes that led to its identification and collection. Fig. 1 shows the details of the concept provided by Tuomi (1999). Alavi and Leidner, (2001) state information is converted to knowledge once it is processed in the mind of individuals and knowledge becomes information once it is articulated and presented in the form of text, graphics, words, or other symbolic forms. Braganza (2004) also proposes a knowledge-information-data (KID) model based on a case study, which suggests knowledge leads to information, which determines data. It reversed the commonly accepted hierarchy, which assumes that knowledge is a product of data and information (Tian et al., 2009). Although the term knowledge management formally entered popular usage in the late 1980s (e.g., conferences in KM began appearing, books on KM were published, and the term began to be seen in business journals), philosophers, teachers, and writers have been making use of many of the same techniques for decades Tian, et al. (2009).

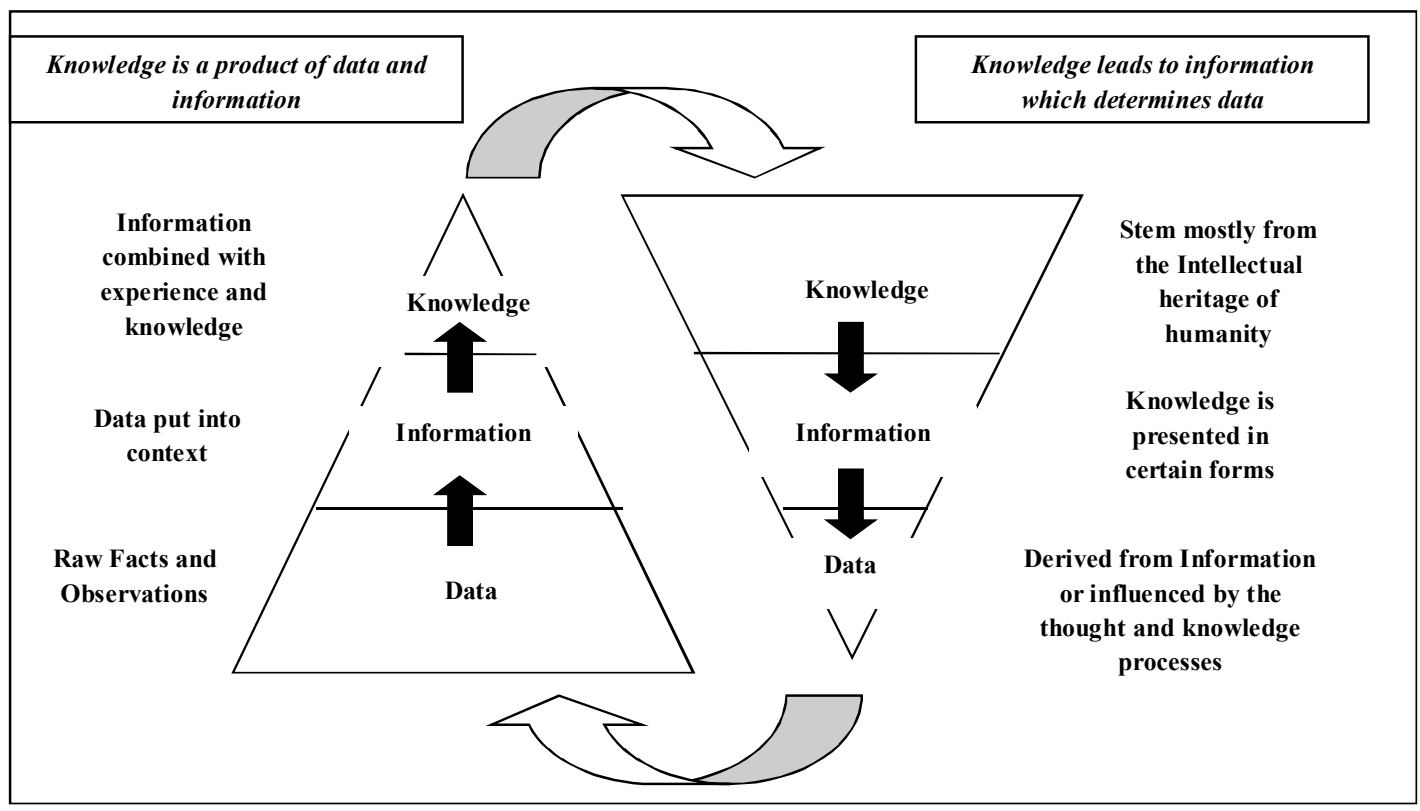

Fig. 1. Hierarchy for Data-Information-Knowledge (Tian et al., 2009) 
Table 2 shows the summary of definitions of data, information and knowledge proposed by the researchers in the field of knowledge management:

Table 2

Definitions of data, information and knowledge (adapted from Awad and Ghaziri, 2006)

\begin{tabular}{|c|c|c|}
\hline Data & Information & Knowledge \\
\hline $\begin{array}{l}\text { Statements about reality } \\
\text { (Acharya, 2000) }\end{array}$ & $\begin{array}{l}\text { Organized, systematized data } \\
\text { (Acharya, 2000) }\end{array}$ & Human interaction with reality (Acharya, 2000) \\
\hline $\begin{array}{l}\text { Unsorted bits of fact } \\
\text { (Dixon, 2000) }\end{array}$ & $\begin{array}{l}\text { Data that has been sorted, analyzed, } \\
\text { and displayed } \\
\text { (Dixon, 2000) }\end{array}$ & $\begin{array}{l}\text { Meaningful links people make in their minds between } \\
\text { information and its application in action in a specific } \\
\text { setting (Dixon, 2000) }\end{array}$ \\
\hline $\begin{array}{l}\text { A representation of a } \\
\text { fact, number, word, } \\
\text { image, picture, or } \\
\text { sound; Measurements } \\
\text { (Applehans et al., 1999) }\end{array}$ & $\begin{array}{l}\text { Data that has been assigned a } \\
\text { meaning } \\
\text { (Liebowitz and Wilcox, 1999) }\end{array}$ & $\begin{array}{l}\text { The whole set of insights, experiences, and procedures } \\
\text { that are considered correct and true and that, therefore, } \\
\text { guide the thoughts, behavior, and communication of } \\
\text { people } \\
\text { (Liebowitz \& Wilcox, 1999) }\end{array}$ \\
\hline \multirow[t]{4}{*}{$\begin{array}{l}\text { A discrete, objective } \\
\text { fact about events } \\
\text { (Davenport \& Prusak, } \\
\text { 2000) }\end{array}$} & $\begin{array}{l}\text { Potential for action; resides in the } \\
\text { user } \\
\text { (Malhotra, 1998) }\end{array}$ & $\begin{array}{l}\text { Ability to turn information and data into effective action } \\
\text { (Applehans et al., 1999) }\end{array}$ \\
\hline & $\begin{array}{l}\text { A statement of fact about } \\
\text { measurements } \\
\text { (Applehans et al.,1999) }\end{array}$ & $\begin{array}{l}\text { An organizational resource consisting of the sum of } \\
\text { what is known } \\
\text { (Holseapple \& Whinston, 1996) }\end{array}$ \\
\hline & $\begin{array}{l}\text { Descriptive knowledge } \\
\text { (characterizing the state of some } \\
\text { past, present, future, or hypothetical } \\
\text { solution) } \\
\text { (Holsapple and Whinston, 1996) }\end{array}$ & $\begin{array}{l}\text { A fluid mix of framed experience, values, contextual } \\
\text { information, and expert insight that provides a } \\
\text { framework for evaluating and incorporating new } \\
\text { experiences and information } \\
\text { (Davenport \& Prusak, 2000) }\end{array}$ \\
\hline & $\begin{array}{l}\text { Data that makes a difference } \\
\text { (Davenport \& Prusak, 2000) }\end{array}$ & $\begin{array}{l}\text { Systematizing and structuring information whose } \\
\text { validity has been established through tests of proof } \\
\text { (Libeskind, 1996) }\end{array}$ \\
\hline
\end{tabular}

\section{KM definition}

$\mathrm{KM}$ is an evolving discipline (Anantatmula \& Kanungo, 2006). KM and its implications are frequently discussed at seminars and conferences (MaÊrtensson, 2000). Researchers and academics have taken different perspectives on knowledge management, ranging from technological solutions to the communities of practices, and the use of the best practices (Bhatt, 2001). The number of companies claiming to work with knowledge management is growing steadily (MaÊrtensson, 2000). However, so far, a standard definition of knowledge management has not been reached (Qi \& Liu, 2010). Some of the definitions proposed by the researchers in the field of knowledge management are given in Table 3.

\section{Knowledge management process}

In today's scenario, knowledge is regarded as the most important strategic resource in organizations, and therefore, KM process is considered critical for organizational success (Dalpati et al., 2010). Knowledge management process with a strategic view can help organizations to manage the information and knowledge it has (Bishwas, 2011). In the year of 2005, Anantamula (2005) reported that knowledge management processes and the resultant knowledge must translate to knowledge management outcomes such as improved communication, and enhanced collaboration; together they lead to improving employee skills thereby leading to higher productivity and better decision making. Table 4 shows a summary of definitions of knowledge management process, proposed by the researchers in the field of knowledge management. 
Table 3

Definitions of KM

\begin{tabular}{|c|c|c|}
\hline S.No. & Author And Year & efinition \\
\hline 1. & Singh and Kant (2008) & $\begin{array}{l}\text { Knowledge management is the deliberate and systematic coordination of an organization's people, technology, } \\
\text { processes and organizational structure in order to add value through reuse and innovation. }\end{array}$ \\
\hline 2. & Qian and Tian (2008) & $\begin{array}{l}\text { Knowledge management is considered as a key part of the strategies to use knowledge to create a sustainable } \\
\text { competitive advantage in organizations. }\end{array}$ \\
\hline 3. & Mathi (2004) & $\begin{array}{l}\text { Knowledge management is a process that helps organizations find, select, organize, disseminate, and transfer } \\
\text { important information and expertise to gain business advantage. }\end{array}$ \\
\hline 4. & Wei and $\mathrm{Bi}(2008)$ & $\begin{array}{l}\text { Knowledge management refers to the set processes or practice of developing in an organization the ability to } \\
\text { create, acquire, capture, store, maintain and disseminate the organization's knowledge. }\end{array}$ \\
\hline 5. & $\begin{array}{l}\text { Davenport and Prusak } \\
(2000)\end{array}$ & $\begin{array}{l}\text { Knowledge management as an effort for discovering the treasure hidden in people's minds and turning it into the } \\
\text { assets of organization in such a way that a great number of people who are engaged in decision making processes } \\
\text { of organization can access and make use of this treasure. }\end{array}$ \\
\hline 6. & Barron (2000) & $\begin{array}{l}\text { A systematic and unified method to recognize, use, and share the accessible experiences and specializations in an } \\
\text { organization }\end{array}$ \\
\hline 7. & Bahra (2001) & $\begin{array}{l}\text { Knowledge management as a general description of culture, processes, fundamentals, and technologies available } \\
\text { in an organization which makes possible the absorption, development, and improvement of knowledge asset of } \\
\text { an organization to reach its strategic goals. }\end{array}$ \\
\hline 8. & 3ahra (2001) & A movement which will dominate the world of future. \\
\hline 9. & $\begin{array}{l}\text { Dongxiao and Jianqing, } \\
(2010)\end{array}$ & $\begin{array}{l}\text { Knowledge management is a process to improve the competitiveness of enterprises and identify the knowledge, } \\
\text { acquire it and play its full role in the process. }\end{array}$ \\
\hline 10. & Beckman (1999) & $\begin{array}{l}\text { The dissemination of knowledge throughout the organization, which results in the improvement of performance } \\
\text { and efficiency of the organization. }\end{array}$ \\
\hline 11. & Cao et al. (2010) & $\begin{array}{l}\text { Knowledge management is the source to improve enterprise core competitive ability in the knowledge economic } \\
\text { ages. }\end{array}$ \\
\hline 12. & enzhi (2010) & he creation, acquisition, sharing, and utilization of knowledge for the promotion of organizationa \\
\hline 13. & & nowledge $n$ \\
\hline 14. & Wang et al. (2011) & $\begin{array}{l}\text { The enterprise knowledge management is an effective interaction organized for realizing the goal of management } \\
\text { between knowledge and valid human acts. }\end{array}$ \\
\hline 15. & Greiner et al. (2007) & $\begin{array}{l}\text { Knowledge management includes all the activities that utilize knowledge to accomplish the organizational } \\
\text { bjectives in order to face the environmental challenges and stay competitive in the market place. }\end{array}$ \\
\hline 16. & Bhatt (2001) & $\begin{array}{l}\text { Knowledge management is a comprehensive process of knowledge creation, knowledge validation, knowledge } \\
\text { presentation, knowledge distribution, and knowledge application. }\end{array}$ \\
\hline 17. & ng and Lie & nowledge management is one of \\
\hline 18. & $\begin{array}{l}\text { Anantatmula and } \\
\text { Kanungo (2006) }\end{array}$ & $\mathrm{M}$ is an evolving discipline. \\
\hline 19. & $\begin{array}{l}\text { Marques and Simon } \\
(2006)\end{array}$ & $\begin{array}{l}\mathrm{M} \text { is considered a managerial system that captures established models of organization and broadens them to } \\
\text { ovide a practical methodology. }\end{array}$ \\
\hline 20. & iney (2001) & nowledge management $(\mathrm{KM})$ is the subject of much literature, discussion, planning and some action. \\
\hline 21. & $\begin{array}{l}\text { Newman and Conrad, } \\
\text { (1999) }\end{array}$ & $\begin{array}{l}\text { Knowledge management is not one single discipline. Rather, it an integration of numerous endeavors and fields } \\
\text { of study. Knowledge management is a discipline that seeks to improve the performance of individuals and } \\
\text { organizations by maintaining and leveraging the present and future value of knowledge assets. Knowledge } \\
\text { management systems encompass both human and automated activities and their associated artifacts. }\end{array}$ \\
\hline 22. & $\begin{array}{l}\text { Department of the Army } \\
\text { Washington (2012) }\end{array}$ & $\begin{array}{l}\text { Knowledge management }(\mathrm{KM}) \text { is the process of enabling knowledge flow to enhance shared understanding, } \\
\text { learning, and decision making. }\end{array}$ \\
\hline 23. & Omona et al. (2010) & $\begin{array}{l}\mathrm{KM} \text { is a discipline that is concerned with the analysis and technical support of practices used in an organization } \\
\text { to identify, create, represent, distribute and enable the adoption and leveraging of good practices embedded in } \\
\text { collaborative settings and, in particular, in organizational knowledge processes. }\end{array}$ \\
\hline 24. & Ahani et al. (2013) & $\begin{array}{l}\text { Knowledge management }(\mathrm{KM}) \text { referred to as the new paradigm of the management area provides an answer to } \\
\text { the country's requirements based on the management of nation's intangible assets. }\end{array}$ \\
\hline 25. & Sen (2009) & $\begin{array}{l}\text { In the organizational context, } \mathrm{KM} \text { refers to identifying and leveraging the collective knowledge in an } \\
\text { organization for facing the competition. }\end{array}$ \\
\hline 26. & Singh and Kant (2008) & $\begin{array}{l}\mathrm{KM} \text { is the deliberate and systematic coordination of an organization's people, technology, processes and } \\
\text { organizational structure in order to add value through reuse and innovation. }\end{array}$ \\
\hline 27. & eng and Tian (2008) & $\begin{array}{l}\text { lowledge management is considered as a key part of the strategies to use knowledge to create a sustainable } \\
\text { mpetitive advantage in organizations. }\end{array}$ \\
\hline 28. & Tong (2009) & $\begin{array}{l}\text { Enterprise knowledge management is essentially a management innovation activity, covering the production of } \\
\text { relevant knowledge, knowledge organization, and knowledge dissemination, knowledge marketing, knowledge } \\
\text { application, knowledge consumption and all aspects of personnel management. }\end{array}$ \\
\hline 29. & Folorunso et al. (2011) & $\begin{array}{l}\text { Knowledge management is a new important information technology-based business paradigm for achieving } \\
\text { competitive advantage, and it is no surprise that it has received so much attention from researchers. }\end{array}$ \\
\hline 30. & Iathi (2004) & $\begin{array}{l}\text { Knowledge management is a process that helps organizations find, select, organize, disseminate, and transfer } \\
\text { important information and expertise to gain business advantage. }\end{array}$ \\
\hline 31. & Lopez et al. (2004) & $\begin{array}{l}\text { Knowledge management is a rather a new phenomenon and is in the initial stages of its exploration. In order to } \\
\text { develop new knowledge and use the knowledge which already exists within organizations, it seems essential to } \\
\text { create an atmosphere of trust and security to encourage innovation, experimentation and risk taking }\end{array}$ \\
\hline 32. & Nonaka (2007) & $\begin{array}{l}\text { Knowledge management is a human resource management exercise than a technology based discipline. It is not } \\
\text { merely state of the art technology used to improve efficiency of the knowledge. Rather it is an exercise about } \\
\text { how people can be motivated, best utilize their knowledge, experiences and enhance the creativity by using state } \\
\text { of the art technology. }\end{array}$ \\
\hline
\end{tabular}


Table 4

Summary of KM Process Definitions

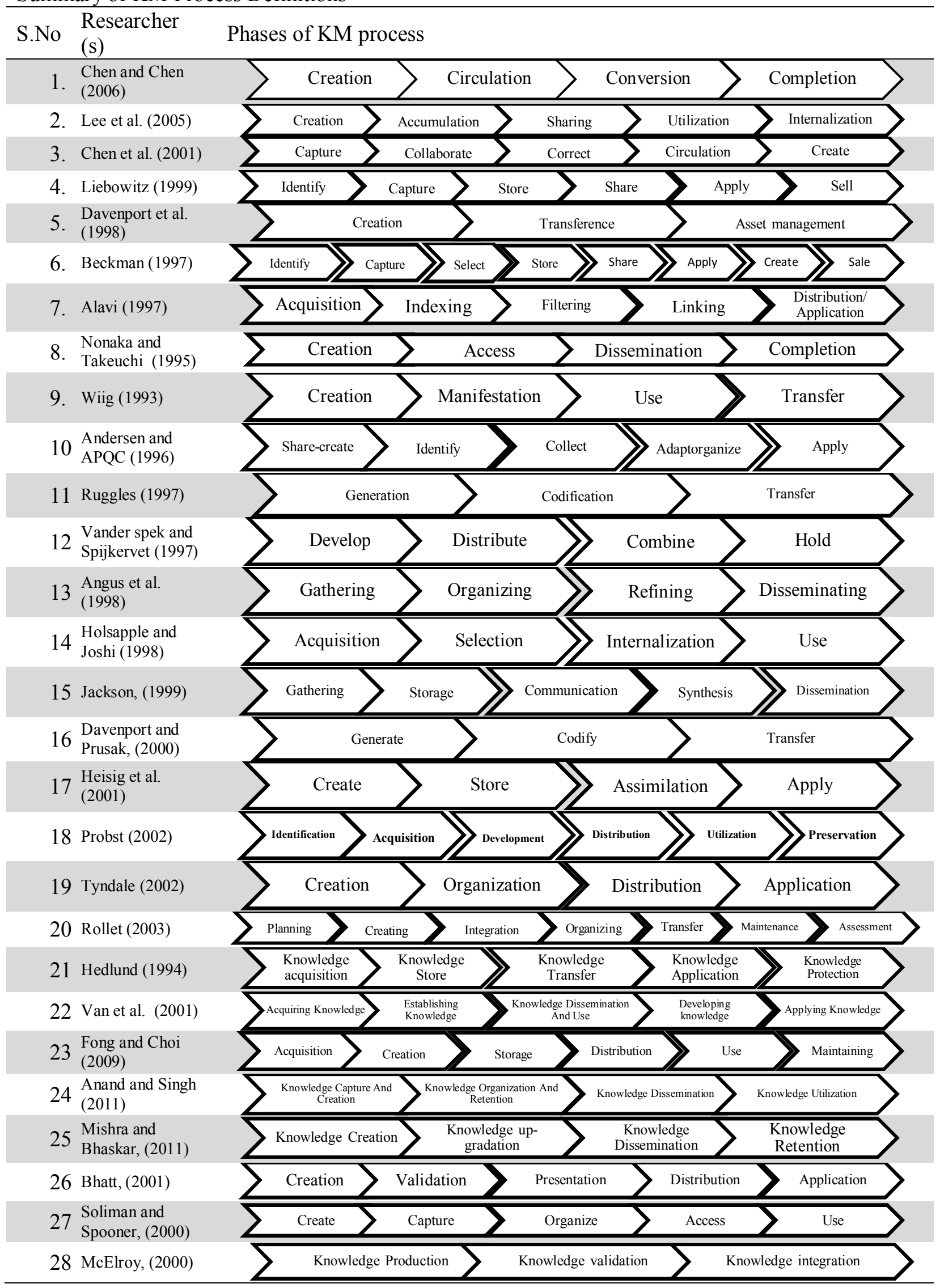




\section{Objectives of KM}

Some of the objectives of KM are listed as follows:

1. To avoid re-inventing of the wheel in organizations or reduce duplication of Knowledgebased activities. Basically the intent is full knowledge utilization (Andriessen, 2004a, b),

2. To facilitate continuous innovation that can be capitalized (Andriessen, 2004a, b),

3. To increase people competencies and thus organizational competencies that would eventually lead to greater competitiveness Andriessen (2004a, b),

4. To improve organizational flexibility towards change and innovation. (Soliman and Spooner, 2000),

5. Create knowledge repository (Davenport et al., 1998),

6. Improve knowledge assets (Davenport et al., 1998),

7. Enhance the knowledge environment(Davenport et al., 1998),

8. Manage knowledge as an asset (Davenport et al., 1998),

9. Supporting innovation, the generation of new ideas and the exploitation of the organization's thinking power; (Levett \& Guenov, 2000),

10. Capturing insight and experience to make them available and usable when, where and by whom required; (Levett \& Guenov, 2000),

11. Making it easy to find and reuse sources of know-how and expertise, whether they are recorded in a physical form or held in someone's mind; (Levett \& Guenov, 2000),

12. Fostering collaboration, knowledge sharing, continual learning and improvement; (Levett \& Guenov,2000),

13. Improving the quality of decision making and other intelligent tasks; (Levett \& Guenov, 2000),

14. To understand the value and contribution of intellectual assets and increasing their worth, effectiveness and exploitation. (Levett \& Guenov, 2000),

15. To make the enterprise act as intelligently as possible to secure its viability and overall success (Wiig, 1993; Dingsøyr, 2002),

16. To otherwise realize the best value of its knowledge assets (Dingsøyr, 2002).

\section{Applications of knowledge management}

Table 5 shows some of the applications proposed by the researchers (Binney, 2001; Bond, 2003).

Table 5

Applications of Knowledge Management

\begin{tabular}{|c|c|c|c|c|c|}
\hline Transactional & Analytical & $\begin{array}{l}\text { Asset } \\
\text { management }\end{array}$ & Process & Developmental & $\begin{array}{l}\text { Innovation and } \\
\text { Creation }\end{array}$ \\
\hline $\begin{array}{l}\text { Case based } \\
\text { reasoning }(\mathrm{CBR})\end{array}$ & $\begin{array}{l}\text { Data } \\
\text { warehousing }\end{array}$ & $\begin{array}{l}\text { Intellectual } \\
\text { property }\end{array}$ & $\begin{array}{l}\text { Total quality } \\
\text { management }\end{array}$ & skills development & $\begin{array}{l}\text { Communities of } \\
\text { practice/ interest }\end{array}$ \\
\hline $\begin{array}{l}\text { Help desk } \\
\text { applications }\end{array}$ & Data mining & $\begin{array}{l}\text { Document } \\
\text { management }\end{array}$ & $\begin{array}{l}\text { Benchmarking } \\
\text { best practices }\end{array}$ & Staff competencies & Collaboration \\
\hline $\begin{array}{l}\text { Customer service } \\
\text { applications }\end{array}$ & $\begin{array}{l}\text { Business } \\
\text { intelligence }\end{array}$ & $\begin{array}{l}\text { Knowledge } \\
\text { valuation }\end{array}$ & $\begin{array}{l}\text { Quality } \\
\text { management }\end{array}$ & Learning & $\begin{array}{l}\text { Discussion } \\
\text { forums }\end{array}$ \\
\hline $\begin{array}{l}\text { Order entry } \\
\text { applications }\end{array}$ & $\begin{array}{l}\text { Management } \\
\text { information } \\
\text { systems }\end{array}$ & $\begin{array}{l}\text { Knowledge } \\
\text { repositories }\end{array}$ & $\begin{array}{l}\text { Business process } \\
\text { reengineering }\end{array}$ & Teaching & Networking \\
\hline $\begin{array}{l}\text { Service agent } \\
\text { support } \\
\text { applications }\end{array}$ & $\begin{array}{l}\text { Decision } \\
\text { support system }\end{array}$ & $\begin{array}{l}\text { Content } \\
\text { management }\end{array}$ & $\begin{array}{l}\text { Process } \\
\text { improvement }\end{array}$ & training & $\begin{array}{l}\text { Multi disciplined } \\
\text { teams }\end{array}$ \\
\hline
\end{tabular}




\section{Benefits, Myths, and errors of knowledge management}

Table 6 shows some of the applications proposed by the researchers.

Table 6

Benefits, Myths and Errors of Knowledge Management

\begin{tabular}{|c|c|c|c|}
\hline S.No. & BENEFITS & $\begin{array}{l}\text { ERRORS } \\
\text { Fahey and Prusak (1998) }\end{array}$ & $\begin{array}{l}\text { MYTH } \\
\text { Awad. and Ghaziri, (2006) }\end{array}$ \\
\hline 1. & $\begin{array}{l}\text { Better decision making } \\
\text { Singh et al. (2006) } \\
\text { Dalkir (2005) } \\
\text { Chase (1997) }\end{array}$ & $\begin{array}{l}\text { Not developing a working definition } \\
\text { of Knowledge }\end{array}$ & Knowledge management is fad \\
\hline 2. & $\begin{array}{l}\text { Smoother collaboration } \\
\text { Singh et al. (2006) } \\
\text { Dalkir (2005) }\end{array}$ & $\begin{array}{l}\text { Emphasizing knowledge stock to the } \\
\text { detriment of knowledge flow }\end{array}$ & $\begin{array}{l}\text { Knowledge management and data } \\
\text { warehousing are essentially the } \\
\text { same }\end{array}$ \\
\hline 3. & $\begin{array}{l}\text { Enhanced learning } \\
\text { Dalkir (2005) }\end{array}$ & $\begin{array}{l}\text { Viewing knowledge as existing } \\
\text { predominantly outside the heads of } \\
\text { individuals }\end{array}$ & $\begin{array}{l}\text { Knowledge management is a new } \\
\text { concept }\end{array}$ \\
\hline 4. & $\begin{array}{l}\text { Improved communication } \\
\text { Chase (1997) }\end{array}$ & $\begin{array}{l}\text { Not understanding that a fundamental } \\
\text { intermediate purpose of managing } \\
\text { knowledge is to create shared context }\end{array}$ & $\begin{array}{l}\text { Knowledge management is mere } \\
\text { technology }\end{array}$ \\
\hline 5. & $\begin{array}{l}\text { Improved employee skill } \\
\text { Dalkir (2005) } \\
\text { Chase (1997) }\end{array}$ & $\begin{array}{l}\text { Paying little heed to the role and } \\
\text { importance of tacit knowledge }\end{array}$ & $\begin{array}{l}\text { Technology distributes human } \\
\text { intelligence }\end{array}$ \\
\hline 6. & $\begin{array}{l}\text { Increased employee satisfaction } \\
\text { Dalkir (2005) }\end{array}$ & $\begin{array}{l}\text { Disentangling knowledge from its } \\
\text { uses }\end{array}$ & $\begin{array}{l}\text { Knowledge management is } \\
\text { another form of reengineering }\end{array}$ \\
\hline 7. & $\begin{array}{l}\text { New or better way of working } \\
\text { Chase (1997) }\end{array}$ & Downplaying thinking and reasoning & $\begin{array}{l}\text { Company employees have } \\
\text { difficulty sharing knowledge }\end{array}$ \\
\hline 8. & $\begin{array}{l}\text { Sharing best practices } \\
\text { Davenport (1998) } \\
\text { Singh et al. (2006) } \\
\text { Dalkir (2005) } \\
\text { Chase (1997) }\end{array}$ & $\begin{array}{l}\text { Focusing on the past and the present } \\
\text { and not the future }\end{array}$ & $\begin{array}{l}\text { Knowledge management works } \\
\text { only within an organization } \\
\text { technology is a better alternative } \\
\text { than face to face }\end{array}$ \\
\hline 9. & $\begin{array}{l}\text { Enhanced the continuity of the } \\
\text { organization } \\
\text { Beijerse (1999) }\end{array}$ & $\begin{array}{l}\text { Failing to recognize the importance of } \\
\text { experimentation }\end{array}$ & $\begin{array}{l}\text { It is no brainer to share what you } \\
\text { know }\end{array}$ \\
\hline
\end{tabular}

\section{Conclusion}

The research paper has shown details of research work conducted by various researchers in the field of knowledge management. From the given literature review we can conclude that the field of KM is very large and it is being refined by various researchers year by year. The literature review has shown the understanding of researchers for knowledge and knowledge management for decades. Literature review also has indicated that yet the term knowledge management is being coined recently but this concept has grown very fast. Today, there are a lot of conferences, books and other study materials available under the banner of KM, which shows the need and importance of KM to the industries and research institutions. Literature has shown about the distinction between knowledge, information and data and the hierarchies. This distinction implies that knowledge is beyond the concepts of data and information. Literature review has also provided researchers have pointed out the various aspects of knowledge, knowledge management and knowledge management processes. All the definitions provided by the researchers help in visualizing the concepts from different perspectives. The research paper has also addressed objectives, applications, benefits, myths and errors associated with KM, which also help researchers to visualize their problem from new perspectives. 


\section{References}

Acharya, J. (2000). What is knowledge. Retrieved December 2013, from www.kmx.totalkm.com/whatisk.html

Ahani, M., Reza, H. B., \& Rostamic, M. (2013). Determining and ranking dimensions of knowlede management implementation using hicks model and fuzzy TOPSIS technique. Management Science Letters, 3, 1-10.

Alavi, M. (1997). KPMG Reat Marwick US: One Gaint Brain. Harvard Business School.

Alavi, M., \& Leidner, D. E. (2001). Knowledge management and knowledge management systems: Conceptual foundations and research issues. MIS Quarterly, 25 (1), 107-136.

Anand, A., \& Singh, M. D. (2011). Understanding knowledge management: A literature review. International Journal of Engineering, Science and Technology, 3 (2), 926-939.

Anantamula, V. (2005). Outcomes of knowledge management initiatives. International Journal of Knowledge Management, 50-67.

Anantamula, V., \& Kanungo, S. (2006). Structuring the underlying relations among the knowledge management outcomes. Journal of Knowledge Management, 10 (4), 25-42.

Andersen, A., \& APQC. (1996). The apparent reality:On knowledge production in the social sciences. Copenhagen: Samfundslitteratur.

Andriessen, D. (2004a). IC valuation and measurement: Classifying the state of the art. Journal of Intellectual Capital, 5 (2), 230-242.

Andriessen, D. (2004b). Making sense of intellectual capital. Burlington,MA: ButterworthHeinemann.

Angus, J., Patel, J., \& Harty, J. (2011). Knowledge management cosmology, information knowledge management process in two learning organizations. Journal of Knowledge Management, 15 (2), 344-359.

Applehans, W., Globe, A., \& Laugero, G. (1999). Managing knowledge. Boston, MA: Addisonwesley.

Awad, G. M., \& Ghaziri, H. M. (2006). Knowledge management. India: Dorling Kindersley (India) Pvt. Ltd, Pearson Education.

Bahra, N. (2001). Competitive knowledge management. London: Plagrave.

Beckman, T. (1997). Methodology for knowledge management. In Harmza, M.H (Eds). International Association of Science and Technology for Development (IASTED) AI and Soft Computing Conference, (pp. 29-32). Calgary.

Beckman, T. (1999). The current state of knowledge management. In J. Libuwitz, The knowledge management hand book (p. CRC Press). Boca Raton.

Beijerse, R. P. (1999). Questions in knowledge management: Defining and conceptualizing a phenomenon. Journal of Knowledge Management, 3 (2), 94-109.

Beng, C., \& Liew, A. (2008). Stategic integration of knowledge management and customer relationship management. Journal of Knowledge Management, 12 (4), 131-146.

Bhatt, G. D. (2001). Knowledge mangement in organizations: Examining the interation between technologiey, techniques and people. Journal of Knowledge Management, 5 (1), 68-75.

Binney, D. (2001). The knowledge management spectrum - Understanding the KM landscape. Journal of Knowledge Management, 5 (1), 33-42.

Bishwas, S. K. (2011). Conceptualization of organization vitality based on strategic knowledge management. Global Journal of E-business \& Knowledge Management, 7 (1), 45-52.

Bond. (2003). An opportunity missed or taken. Retrieved from British overseas NGOs for development: www.bond.org.uk

Borron, T. (2000). A smarter frankenstein: the merging of e-learning. Alexandria,VA: ASTD.

Braganza, A. (2004). Rethinking th data-information-knowledge hierarchy: Towards a case-based model. International Journal of Information Management, 24 (4), 347-356.

Cao, M., Fan, J. J., Lu, H. P., \& Chen, J. L. (2010). Evaluation of enterprise knowledge management performance based on gap analysis. Proceedings of ICMIT Coference (pp. 894-897). IEEE. 
Chase, R. L. (1997). The knowledge based organization: An international survey. Journal of Knowledge Management, 1 (1), 38-49.

Chen, M. Y., \& Chen, A. P. (2006). Knowledge management performance evaluation: A decade review from 1995 to 2004. Journal of Information Sciences, 32 (1), 15-36.

Chen, M. Y., Tsai, M. J., \& Wu, H. J. (2001). The research of KM opration module in science \& technology industry - Case study of TSMC,in: S-C.T. Chou. Proceedings of the twelfth international conference of information management. Taiwan. CSIM Press.

Dalkir, K. (2005). Knoweldge management in theory and practice. Burlington: Elsevier ButerworthHeinemann.

Dalpati, A., Rangnekar, S., \& Birasnav, M. (2010). Knowledge management and supply chain flexibility performance in indian manufacturing industry: An empirical study. Global Journal of E- business and Knowledge Management, 6 (1), 10-16.

Davenport, T. H., \& Prusak, L. (2000). Working knowledge: How organizations manage what they know. Boston, MS: Harvard business school.

Davenport, T., De, L. D., \& Beers, M. (1998). Sucessful knowledge management projects. Sloan Mangement Review, 39 (2), 43-57.

Deng Qian-Wang, Tian Yong-Ziang.(2008).Modeling knowledge management processes from perspectives of knowledge agents. IEEE Conference Transactions, (pp. 1-4).

Dingsoyr, T. (2002). Knowledge management in medium sized software consulting companies. Norway: Doktor Ingeniør Thesis, Department of Computer and Information Science, Tapir Trykker.

Dixon, N. M. (2000). Common knowledge. Boston, M.A: Harvard business school press.

Dongxiao, N., \& Jianqing, L. (2010). Evaluation of the level of generation enterprise knowledge management based on AHP and GRA. IEEE Conference Transactions, (pp. 1-4).

Fahey, L., \& Prusak, L. (1998). The eleven deadiest sins of knowledge management. California Management Review, 40 (3).

Folorunso, O., Adewale, G., Ogunde, A. O., \& Okesola, J. O. (2011). Pinch analysis as a knowledge management tool for optimization in supply chain. Journal of Computer and Information Science, 4 (1), 79-89.

Fong, P. S., \& Choi, S. K. (2009). The processes of knowledge management in professional services firms in the construction industry: A critical assessment of both theory and practice. Journal of Knowledge Management, 13 (2), 110-126.

Greiner, M. E., Bohmann, T., \& Krcmar, H. (2007). A strategy for knowledge management. Journal of Knowledge Management, 11 (6), 3-15.

Guenov, M., \& Lovett, G. (2000). A methodology for knowledge management implementation. Journal of Knowledge Management, 4 (3), 258-269.

Hedlund, G. (1994). A model of knowlede management and the N-form corporation. Strategic Management Journal, 15, 73-90.

Heisig, P., Mertins, K., \& Vorbeck, J. (2001). Concepts and best practices in Europe (2nd ed.). Berlin Heidelbery: Springer-Verlog.

Holsapple, C. W., \& Joshi, D. (1998). In search of a descriptive framework for knowledge management: Preliminary delphi results. College of business and economics, University of Kentucky.

Holsapple, C. W., \& Whinston, A. B. (1996). Decision support systems. Minneapolis, MN: West publishing company, 11-24.

Jackson, C. (1999). Process to product - creating tools for knowlede management hype. Journal of Quality and Participation, 21 (4), 58-60.

Lee, K. C., Lee, S., \& Kang, I. W. (2005). Knowledge management: Measuring knowledge management performance. Information and Management, 42 (3), 469-482.

Liebesking, J. P. (1996). Knowledge strategy and the theory of the firm. Strategic Management Journal , 93-107. 
Liebowitz, J. (1999). Key ingredients to the sucess of an organiztion's knowledge management strategy. Knowledge and Process Management, 6 (1), 37-40.

Liebowitz, J., \& Wilcox, L. C. (1999). Knowledge Management And Its Integrative Elements. Boca Raton: CRC Press.

Liew, C. B. (2008). Strategic integration of knowledge management and customer relationship management. Journal of Knowledge Management, 12 (4), 131-146.

Lopez, S. P., Peon, J. M., \& Ordas, C. J. (2004). Managing knowledge: The link between culture and organizational learning. Journal of Knowledge Management, 8 (6), 93-104.

MaErtensson, M. (2000). A critical review of knowledge management as a management tool. Journal of Knowledge Management , 4 (3), 204-216.

Maheshwarkar, M., \& Sohani, N. (2013). Combining AHP-TOPSIS based approach for the evaluation of knowledge sharing capabilities of supply chain partners. Management Science and Engineering, 7 (3), 27-32.

Malhotra, Y. (1998). Deciphering the knowledge management type. Journal of Quality and Participation, 21 (4), 58-60.

Manual, F. (2012). Knowledge management operations. Washington: Department of Army.

Marques, D. P., Jose, O. F., \& Simon, G. (2006). The effect of knowledge management practices on firm performance. Journal of Knowledge Management, 10 (3), 143-156.

Mathi, K. (2004). Key sucess factors for knowledge management, Master Thesis MBA. Lindau, Germany: University of applied sciences/FH kempten.

McElroy, M. W. (2000). Integrating complexity theory, knowledge management and organiztional learning. Journal of Knowledge Management, 4 (3), 195-203.

Mishara, B., \& Bhaskar, U. (2011). Knowledge management process in two learning organizations. Journal of Knowledge Management, 15 (2), 344-359.

Myburgh, S. (2000). The convergence of information technology and information management. The Information Management Journal, 34, 4-16.

Newman, B., \& Conrad, K. (1999). A framework for characterizing knowledge management methods, practices and technologies. West Richland: The knowledge management forum.

Nonaka, I. (2007). Strategy as distributed phronesis: Knowledge creation for the common good. Proceedings of the International Productivity conference. Bankok, Thailand.

Nonaka, I. (1998). The knowledge creating company. Harvard Business Review, 21-46.

Nonaka, I., \& Takeuchi, H. (1995). The knowledge creating company. Oxford university press.

Omona, W., Weide, T. V., \& Lebuga, J. (2010). Using ICT to enhance knowledge management in higher education: A conceptual framewok and research agenda. International Journal of Education and Development using Information and Communication Technology, 6 (4), 83-101.

(2012). PinkScan Assessment Report. Office of Information Technology. University of Alaska.

Probst, G. (2002). Managing knowledge: Building blocks for sucess. West sussex, England: Wiley.

Qi, R.-g., \& Liu, S.-J. (2010). Research on comprehensive evaluation of enterprises knowledge management capabilities. Seventeenth IEEE international conference on management science and engineering, (pp. 1031-1036). Melbourne, Austrailia.

Rolllett, H. (2003). Knowledge management, processes and technologies. Kluwer academic publishers.

Ruggles, R. (1997). the state of the notion: knowlege management in practice. California Management Review, 80-89.

Sen, S. (2009). Knowledge management and learning organizations: A case study on private computer training institutes. Global Journal of E-business \& Knowledge Management, 5(1), $27-$ 32.

Singh, M., \& Kant, R. (2008). Knowledge management barriers: An interpretive structural modeling approach. International Journal of Management Science and Engineering Management, 3(2), 141150.

Singh, M., Shankar, R., Narain, R., \& Kumar, A. (2006). Survey of knowlede management practices in indian manufacturing industries. Journal of Knowledge Management, 3 (2), 110-118. 
Sooliman, F., \& Spooner, K. (2000). Straties for implementing knowlede management: role of hman reseouces management. Journal of Knowledge Management , 4 (4), 337-345.

Storey, J., \& Barnett, E. (2000). Knowledge management initiatives: Learning from future. Journal of Knowledge Management , 4 (2), 145-156.

Tian, J., Yoshiteru, N., \& Andrzej, P. W. (2009). Knowledge management and knowledge creation in academia: A study based on surveys in a japanese research university. Journal of Knowledge Management, 13 (2), 76-92.

Tong, Y. (2009). Summary research of risk identification in the process of knowledge management. IEEE Second international conference on future information technology and management engineering (pp. 210-213). IEEE computer society.

Tuomi, I. (1999). Data is more than knowledge:Implications of the reversed hierarchy for knowledge management and organizational memory. Proceedings of the thirty secondth Hawai international conference on systems sciences. Los Alamitos, CA: IEEE computer society press.

Tyndale, P. (2002). A taxonomy of knowledge management software tools: origins and applications. Evalution and Program Planning, 25, 183-190.

Van, Z. S., Streumer, J. N., \& Stooker, M. (2001). Problems in knowledge management: A case study in a knowlede - intensive company. International Journal of Training and Development, 5 (3), $168-184$

Vander spek, R., \& spijkervet, A. (1997). Knowledge management: Dealing intelligently with knowledge. In J. Liebowitz, \& L. Wilcox, Knowledge management and its integrative elements. Newyork: CRC Press.

Wang, X., Cao, X., Xiu, H., \& Zhang. (2011). Knowledge management performance evaluation based on traingular fuzzy number and theory of knowledge cycle. IEEE Press. China.

Wei, J. Y., \& Bi, R. (2008). Knowledge management performance evaluation based on ANP. Seventh international conference on machine learning and cybernetics, (pp. 12-15). Kunming.

Wells, H. (1938). World brain. Garden City,Newyork: Doubleday, Doran \& Company.

Wenzhi, P. (2010). Research on the evaluation of knowledge management performance of enterprise. International Conference of Information Science and Management Engineering (pp. 68-71). IEEE computer society press.

Wiig, K. (1993). Knowledge management foundations. Arlington,TX: Schema press.

Zack, M. H. (1999). Manageing codified knowledge. Sloan Management Review, 40, 45-58.

Zhao, C. Y. (2011). Research on enterprise knowledge transfer model and performance evaluation based on knowledge value chaing. MSIE Conference (pp. 865-869). IEEE Transaction. 